\title{
建設用移動ロボットの 走行・位置決め制御
}

\author{
汐川孝**
}

\section{1. はじめに}

建築現場では, 作業空間が広いために製造業で用いら れている定置式の産業用ロボットに代って, 移動機能を 備えたロボットの要請が強い.これまでも清掃ロボット や床左官ロボット，検査ロボットなど移動型のロボッ ト・自動化装置が数多く開発されてきている. 移動機能 を備えることにより, ある種の作業では, 作業能率を大 幅に向上させたり, 従来の仮設工事が不要になるなどの 効果をあげている. しかし，ナビゲーションや位置決め 制御, 動作供給方法, 人間や口ボットに対する安全対策 などの新らたな技術課題も生じている.

本報では, 位直決め制御における建築現場の特殊性に ついて述べると共に、これまで関連した 3 件の開発事例 を紹介する.なお，ここでは自動化装置も含めた広い意 味でロボットと称することとする.

\section{2. 建築現場における移動ロボットの特殊性}

\section{1 移動機能を備えた建築工事用ロボットの現状}

これまでに約 50 数種の建築工事用ロボットが開発さ れてきており,このらちの約 65\% が何らかの移動機能 を有している.これら開発された建築工事用口ボットの 移動機能に関する主な仕様を表 1 に示す.

開発対象となっている作業は，軀体工事から仕上工事， 保全工事までのほぼ建築工事の全作業に瓦っており，い ずれも広い範囲に互って移動しながら作業が行われるも のである. その作業内容は, 吹付け, ハンドリング, 塗 装, 検查, 清掃・ケレンなど多岐に瓦っている.また, ロボットの作業動作についても, 移動しながら作業を行 うものや移動後停止して作業を行うものなどがある.

移動対象空間では, 水平面の移動を対象としたものが 移動型の建築工事用ロボットの約 65\%を占めているが, 建物外壁の垂直面の移動を対象にした外壁塗装, 壁面診

\footnotetext{
原稿受付 1990 年 1 月 12 日

* Navigation/Positioning Control of Mobile Robots for Construction

**(株)大林組 技術研究所
}

断作業用のロボットや柱や搭状構造物の軸方向に移動す るロボットなどもある. さらに, 配置された鉄筋上や未 だ固まらないコンクリートの中, グレーチング上での移 動などその移動対象空間は様々である.

これまで開発された移動型の建築工事用ロボットの制 御方式では, 可変シーケンスあるいはプログラム可能な 自動運転方式が全体の約 $46 \%$ と最も多く, 次いでシー ケンス制御及び手動運転方式がそれぞれ約 29\%，26\% となっている.この建築工事用ロボットの自動運転方式 では, 無軌道方式が約 $62 \%$ を占めており, 残りは軌道 を設定するタイプであるが，この軌道方式には，比較的 設定や変更が容易にできるものが採用されている．また， これらの自動運転方式では, ニーザーが軌道データを入 力する方式や障害物を自動的に検出して知らせる方式が 多く採用されているが，軌道データの自動作成や障害物 の自動回避動作を行なら高度な機能を備えたものは, 自 動運転方式の約 $15 \%$ とまだ少ない.

こうした軌道データの自動作成や障害物回避の機能実 現には, 位置検出や位㯰決めにおける高い精度と高度の 制御技術が必要であり, 一部にジャイロやレーザーナビ ゲータ, ITV カメラによる画像処理などによる位置検 出方式が採用されている. しかし, 移動型の建築工事用 ロボットの位置検出方式の大部分は, 移動した距離を車 輪等の回転量のみから算出するタイプ（約 50\%）であ る.

これまでに開発されてきている移動型の建築工事用口 ボットは, 様々な領域において, 様々な移動方式, 位置 決め方式が採用されているが，まだ技術的，実用的に十 分な移動技術とは言えず，現状は，より有効なものの模 索段階と見ることができる.

\section{2 建築現場における移動ロボットの要件}

建築工事では, 広い空間の中で作業を行うため移動機 能は不可欠である. しかし, 製造業を中心に開発されて きた搬送などの移動ロボットをそのまま現場に適用する には, 幾つかの問題がある. 以下, 建築現場での移動口 ボットに要求される機能や制約条件を簡単に示す.

- 建築現場の作業空間は, 工事の進行と共に変化するた 


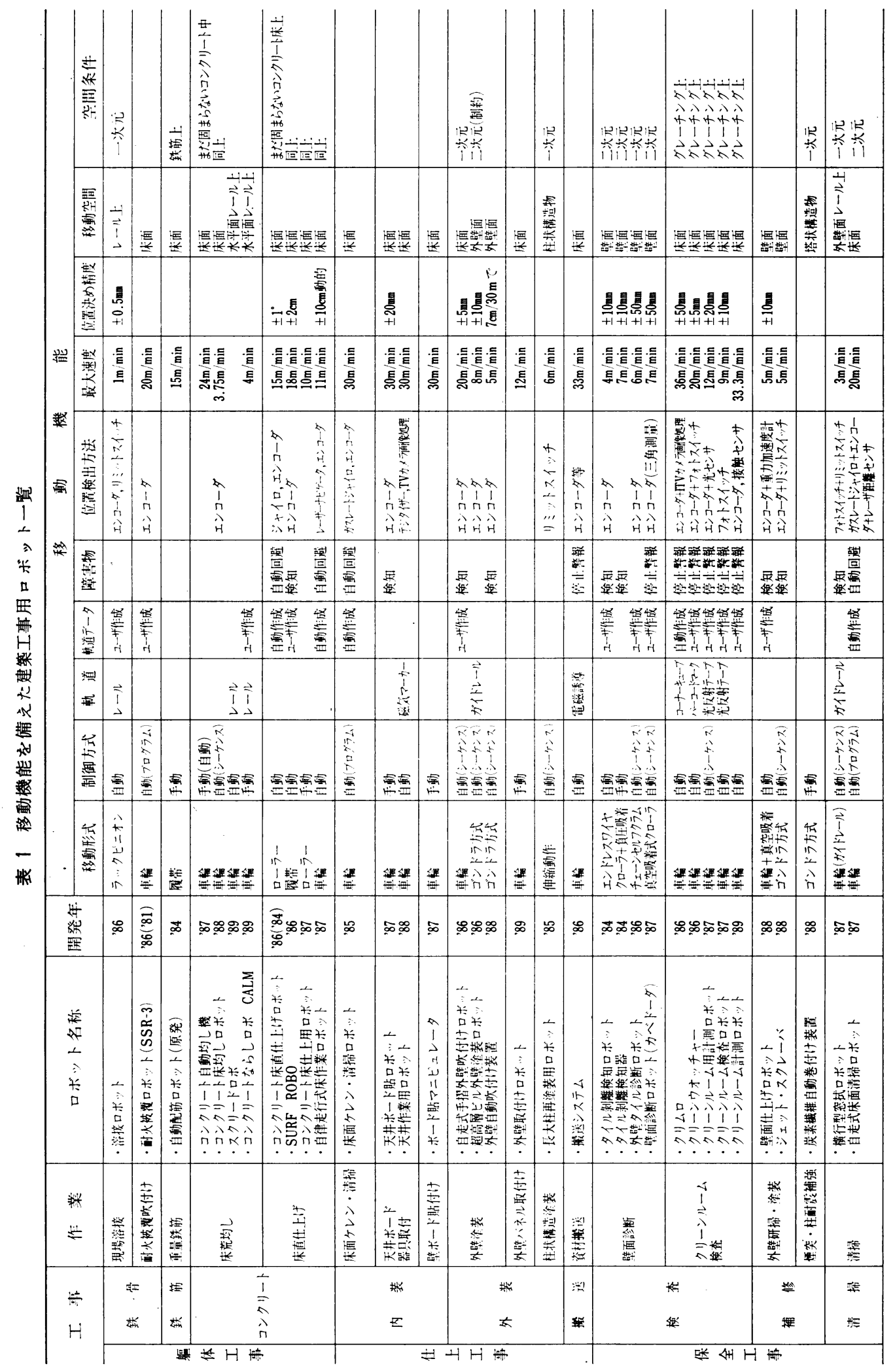




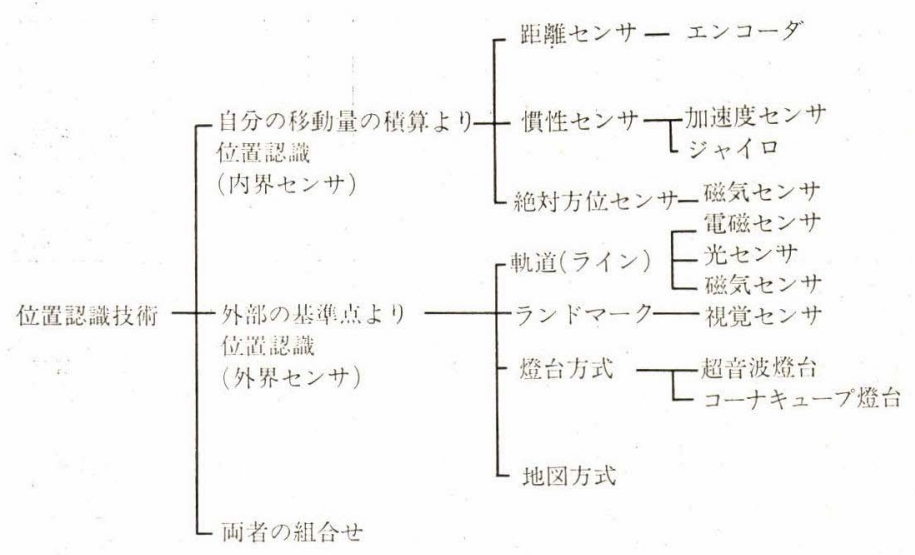

図 1 位置認識技術の現状

表 2 主な仕様（壁面検査ロボット）

\begin{tabular}{|c|c|}
\hline 構 成 & 壁面自走車十計測器 \\
\hline 能 & $\begin{array}{l}\text { 走行速度 : 上昇 } \max 5 \mathrm{~m} / \min \\
\text { 動作 : 上.下, } \mathrm{S} \text { 字走行, 回転 }\left( \pm 90^{\circ}\right) \text {, 横行 } \\
\text { 樻載荷重 }: 10 \mathrm{~kg} \text { 以内 }\end{array}$ \\
\hline 制御 & マニュアル運転, 自動運転 \\
\hline センサー & 傾斜センサ, 開口部・障害物センサ, 圧カセンサ \\
\hline 計 測 器 & 超音波計測器，T V カメラ \\
\hline 外径寸法 & (長さ) $1,060 \times$ (幅) $830 \times$ (高さ) $330 \mathrm{~mm}$ \\
\hline
\end{tabular}

め, 移動経路も常に変わる.このため任意に経路設定 できる方法が求められる

・作業空間の変化に伴い移動時の障害も多く, こうした ものの認識や回避についての高度の機能が求められる

・作業空間が屋外にあるため, 雨や風, 埃などの撖しい 耐環境条件でも使用できることが求められる

・移動しながらの作業が中心になるのでリアルタイム の位置計測や高い位置決め精度が求められる

・建築工事用ロボットには，特に高い信頼性が求められ ている．このためいくつかの位置決め方式を併用する などの対策が必要である

・建築現場では, 作業者とロボットが混在して作業を行 うことが前提になり，これに対する安全対策が不可欠 である

\section{3. 移動・位置決め制御技術の現状}

これまで製造業を中心に適用されてきた移動ロボット の大部分は, 床に設けた電線や光反射テープ, 磁気テー プなどの軌道によって, 誘導されるものである.これに 対して, 建設業や非製造業では, 固定的な軌道に代わっ て任意汇設定された移動経路をロボット自身の現在位置
写真 1 壁面検査口 ボット外観

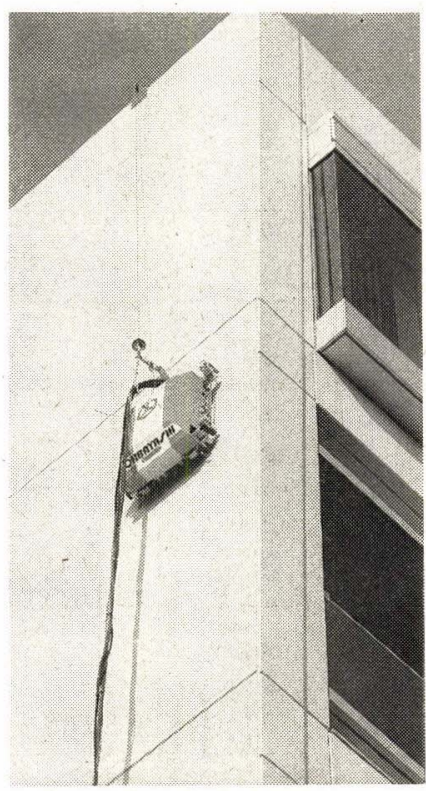

を認識し，自動補正しながら正しく走行する機能（自律 走行）を備えたロボットが要求されている.こうした自 律走行を備えたロボットでは、口ボットの現在位置を正 確に把握する位置認識技術と予定位置への修正を行なら 誘導技術の双方が重要な開発課題になっている.

これまで研究・開発されている位置決めのための認識 方法をセンサ中心に分類し，图１飞示す.

(1) ロボット自身の移動量から位置を求めるもの（内 界センサ）

この方式では, ロボット本体の移動距離及び方位の変 化量を常時積算していくものである，誤差が生じた場合 には，累積する欠点があるが，方法が簡単なため最も多 く採用されている。このため一定距離あるいは時間毎に ロボットの位置と現状の位置との補正を行う必要がある. 最近, 高精度地磁気センサを用いた自律ロボットが開発 


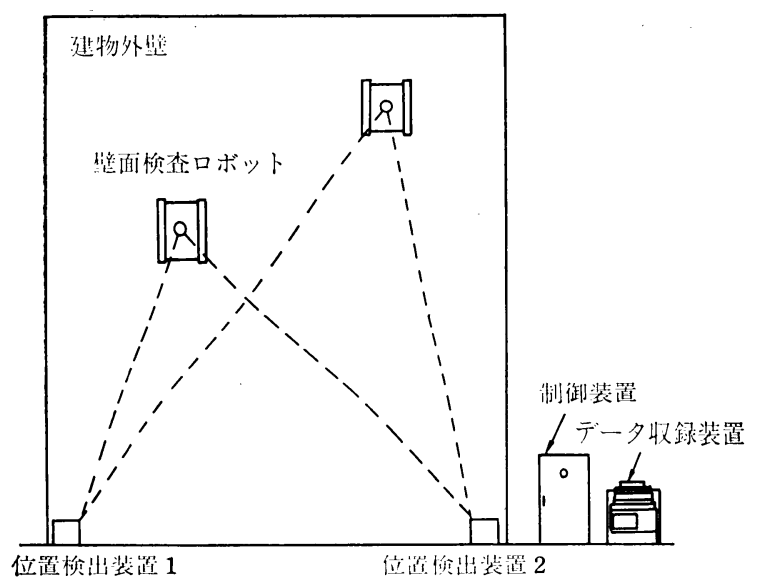

図 2 壁面検査ロボットの位置検出方法

され, 補正の回数は減少したものの, 問題の解消には至 っていない.

(2) 外部基準点から位置を求めるもの（外界センサ） この方式では, ロボットの外部に設けた基準点の絶対 的位置情報をあらかじめに入力しておく、ロボットは, この外部基準点との位置を計測しながら，自分の絶対的 位置を算出するものである. 誤差が生じた場合でも累積 することがないという特徵がある.

この方式には，これまでの軌道を敷設する方法から経 路の要所にマークを設置するもの,ささらには, 走行の経 路に関係なく広範囲の走行の基準点になる燈台を設置す るものがある. また, 走行経路に依存しない基準点とし て, 走行する環境の特徵点の座標（いわゆる地図情報） を入力する方法も幾つか提案されている. 走行経路每に 基準点を変更せずに行える方法が望ましい，

(3) 内界センサと外界センサの組合せたもの

この方式は，上記の二つの利点を合せ持った方式であ る. 外部基準点の情報の得られない時は, 自分の移動量 からの位置決めを行う。そして, 再び基準点からの絶対 的位置情報が得られる時には, 移動量に基づく自分の座 標を補正するので, 安定して高い精度が得られ, 自由度 も高くなる.

\section{4. 開 吐 事 例}

\section{1 壁面検查ロボットの位置決め方式}

\subsection{1 ロボットの概要}

壁面検査ロボットは，鉄筋コンクリート造の構造物の 外壁面の劣化状態を検査するために開発したものである. 本ロボットは, 独立した多数の真空吸着室が連なったク ローラにより壁面や天井面に吸着し, 二次元的に走行す

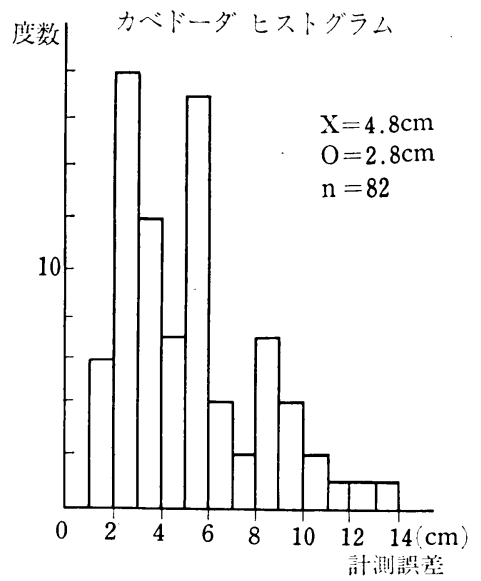

図 3 壁面検査ロボットの位置計測誤差

ることができる、そして，ロボットに搭載した各種の計 測器により, 外壁面の仕上げ層（タイル，モルタル， ב ンクリートなど）の剝離の有無, ひび割れなどの劣化状 態を調查，記録することができる，その主な仕様を表 2 に, 外観を写真 1 亿示す.

本ロボットの主な構成は, 計測器のセンサ部を搭載し た壁面走行台車と地上部に設置する制御装置, 計測装置, データ収録装置及び位置検出器から成る.

4.1 .2 位置決め方式についての要求機能・条件 本ロボットの位置決め方式についての主な要求項目や 条件は, 以下の通りである.

・ロボットは壁面を二次元的に移動して劣化状態を調べ るため,これに追随して，二次元的に位置計測できる こと

・ロボットの計測動作には，一定距離毎に停止して計測 するものと連続して計測するものがある．ロボットの 動きに連動してリアルタイムに位置計測できること

・ロボットは壁面を自力走行するため, 位膡決め装置は 極力小型軽量化されたものであること

・劣化部分の絶対的な位置を正確に求めること（クロー ラの回転量からでは誤差が大きい)

\section{1 .3 位置計湘システム}

上記の条件から, 地上部に 2 つの基準点を設け，この 位置からロボット本体までの距離を求めて，ロボットの 絶対位置を算出する位置計測方法（図 1 の登台方式の一 種）を採用した．2つの基準点には，ロボット本体の動 きに応じて，極細のワイャーヶーブルを引き出したり， 巻き込んだりしながら一定張力に保ち，その引き出し長 さをリアルタイム、オンラインで出力する位置検出装置 を設置している．図２に示すようにロボットの走行に追 
衰 3 主な仕様（クリーンルーム検査ロボット）

\begin{tabular}{|c|c|}
\hline 構 成 & 自律走行台車・多関節アーム \\
\hline 能 & $\begin{array}{l}\text { (1)プローブ走査部 } \\
\text { ・速度 }: 60 \mathrm{~mm} / \mathrm{s} \text { 精度 }: \leqq 2 \mathrm{~mm} \\
\text { ·範囲 }: 700 \times 1500 \mathrm{~mm} \text { 以内 } / 1 \text { 回 } \\
\text { (2)台車部 } \\
\text { 速度 }: \text { 自動, } 18 \mathrm{~m} / \mathrm{min}, \text { マニアル, } 36 \mathrm{~m} / \mathrm{min} \\
\text { 精度 }: \pm 50 \mathrm{~mm}\end{array}$ \\
\hline 制御 & 無線マニアル操作, 全自動 \\
\hline センサ & 視覚センサ：CＣＤカメラ, 障害物センサ \\
\hline 動 力 源 & ・バッテリー(連続 $5 〜 8$ 時間 $)$ \\
\hline 外形寸法 & 台車部：1000×750×895(1590全高) \\
\hline
\end{tabular}

随して，L 1，L 2 の長さがデータ収録用コンピュータに 転送され, 三角測量の要領からロボットの中心位置 $(\mathrm{X}$, Y）が算出される.この算出は，一定時間サイクル毎に 求められ，劣化現象が見つかった時に結果と共に記録さ れる。

4.1.4 測定精度及びその他

ワイヤーケーブルの長さ測定は, エンコーダにより行 っているが, 直線性も高く良好な結果を示している.

図 3 に, $15 \mathrm{~m} \times 10 \mathrm{~m}$ の壁面で実施した本位置計測シ ステムによる誤差の分布を示す. 平均で, $4.8 \mathrm{~cm}$ と比 較的高い精度であることが分かった.

この方式では，(1)ロボット本体への装置搭載がなく重 量負担がない，(2)絶対位置の計測なので誤差累積がない, (3)原理が簡単なので開発費も安く, 保守も容易である, などの利点がある.

\section{2 クリーンルーム検査ロボットの位置決め方式}

\subsection{1 ロボットの概要}

本ロボットは, クリーンルームの性能を確認・維持す るために行ら検査作業を人間に代わって行らものである. 単調で重労働な検査作業から作業者を解放することや検 査作業に伴ら発塵量を少なくすること，検査の精度を向 上させることが目的である. クリーンルーム内を走行し ながら，天井フィルターからのもれを検出するリークテ ストと室内の塵埃量を計測する清浄度テストを行ら。ロ ボットは, 自律走行台車と測定用の多関節アームから構 成されている. 主な仕様を表 3 に示す.

4.2 .2 位置決め方式についての要求機能・条件

本ロボットの位置決め方式についての主な要求や条件 は, 以下の通りである.

・リークテスト時には, $\pm 5 \mathrm{~cm}$ 程度の位置精度や正し い姿勢（向き）が必要である

・清浄度テストは, 許容された経路で移動し, 所定の位 置で計測する必要があるまた，これらの位置は時々

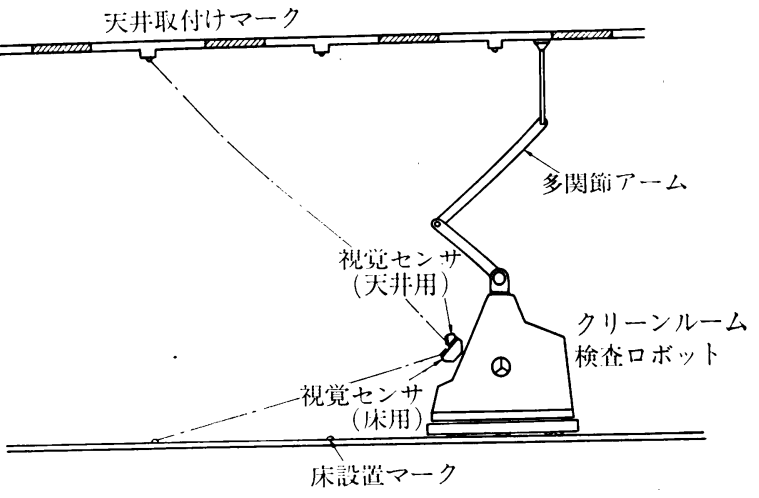

図 4 クリーンルーム検査ロボット位置決め方法

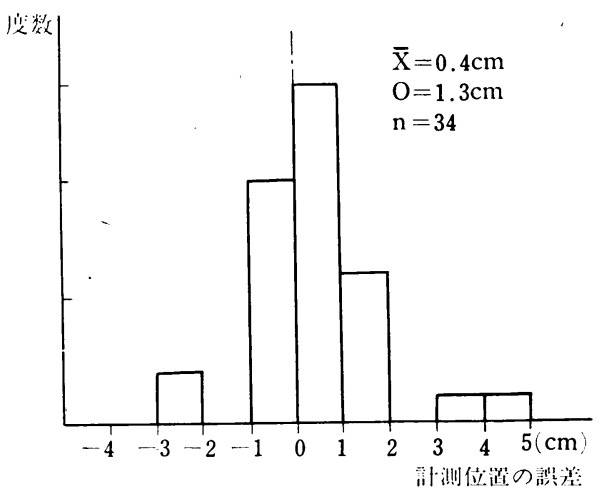

図 5 クリーンルーム検査ロボットの位置決め誤差

変更されるのでこれに追随できる方法であること ・室内の床は, グレーチングが主であり, 車輪のスリッ プなどが予想される，また，電磁誘導など従来の軌道 敷設はできない

・室内の空気送流の乱れになる設備を設けることはでき ない

\section{2 .3 位置決め制御システム}

本ロボットでは, 上記の条件より, 高い走行精度を得 るために，外部にマークを敷設し，このマークを基準に して位置決めを行う方法（図1 のランドマーク方式）を 採用した。 マークは，口ボット本体から投射された光を ロボットに返す光反射型のものである. ロボットの走行 経路にそって，1〜2 $\mathrm{m}$ おきに配置する. ロボットは， 視覚センサである CCD カメラでマークを認識し，その 画像におけるマーク位置から、ロボット本体の向きや位 固を算出し，次の走行制御にフィードバックすることに より, 正しい位置決め (誘導) を行なう (図 4 参照).

本ロボットでは, 测定作業に応じて, 次の二つの制御 方式を用いている.

リークテスト時には, テストするクリーンルームの大 
表 4 主な仕様（床作業ロボット）

\begin{tabular}{|c|c|}
\hline 構 成 & ツイントロウェル・台車率引式 \\
\hline 性能 & $\begin{array}{l}\text { 仕上げ能力: 平均約 } 500 \mathrm{~m}^{2} / \mathrm{h} \\
\text { 走行速 度: } 0 \sim 10 \mathrm{~m} / \mathrm{min} \\
\text { 連続作業時間: } 4 \text { 時間以上 }\end{array}$ \\
\hline 制 御 & 無線式マニュアルコントロール. 全自動 \\
\hline センサ & 開口部・障害物センサ \\
\hline 動力 源 & エンジン発電機搭載 \\
\hline 外径寸法 & (幅) $1,560 \times($ 長さ) $1,985 \times($ 高さ $) 1,100(\mathrm{~mm})$ \\
\hline
\end{tabular}

きさやフィルターの寸法, 天井高などのデータ入力から， 室内の走行経路及び計測動作のデータを自動発生させ, その動作データに基ついて走行・計測を行う. その位置 決め制御は, 天井悈木に取付けたマークを認識して行う 方法である. 清浄度テスト時には, 床にマークを設置し, そのマーク (複数) の配置のパターンから, 右折, 左折, Uターン及び通過を判断して，作業動作を行う方法であ る. マークの配置がロボットへの教示の一部になってい る.

\subsection{4 测定精度及びその他}

リークテスト時の位置決め精度を図 5 に示す. 毎分 $18 \mathrm{~m}$ の速度による自動運転で, $122 \mathrm{~cm}$ 毎に位置決めを 行った時の誤差である. 平均 $0.4 \mathrm{~cm}$, 偏差 $1.3 \mathrm{~cm}$ と大 変高い精度で位置決めを行っていることが分かる.この 方式では，11マークによる軌道設定であるための簡単に 設置及び変更ができること，(2)視覚センサであるため， 床構造に影響されない, (3)高い精度が得られるなどの利 点がある.

\section{3 床作業ロボットの位置決め方式}

\subsection{1 ロボットの概要}

床作業ロボットは、コンクリート㦿の直仕上げ作業や 床面のケレン清掃などの作業を走行しながら行らもので ある.これらの作業は，比較的単調であるが人手中心で あり, 長時間に互って中腰姿勢を続けるためかなり苦渋
な作業である，また，直仕上げ作業は，作業時間が深夜 にまで至るなどの問題があり, 早くから自動化が望まれ ていた。

本ロボットは, 自律走行機能を持った走行台車部と作 業機能を持つ作業装置の分割型で, 小型・軽量化を進め ると共に, 動力減や制御装置を搭載した自立性の高いも のを目指した. ロボットの主な仕様を表 4 に, 外観を図 6 に示す.

\subsection{2 位置決め方法についての要求機能・条件} 本ロボットについての要求・条件を以下に示す.

-この種の作業は, 広い床全面に渡って走行するため, 高い走行精度が要求される. 誤差が大きい程, 重ね代 を大きくせざるを得ず，作業能率が減少する. ここで は，約 $10 \mathrm{~cm}$ 以内の走行制御を目標にした

・床面自身が作業対象なので，床への軌道敷設ができず， また天井はまだない場合が多い

・走行距離の積算方式では，スリップの影響が大きいの で, 外界センサによる方式が必要である

- 走行経路は, 毎回変わるので, 基準点の設定方法は, この影響を受けないものが必要である

・移動空間が広いので, 一度に教示できる範囲や基準点 設定の間隔を大きくする必要がある

\section{3.3 位置決め制御システム}

上記の要請からレーザーによる自己位置検出装置を口 ボットに搭載し, ロボットの絶対位置を常時認識しなが ら走行制御するシステム（図 1 の燈台方式）を開発した. このレーザー位置検出装置は, レーザー光を水平方向に 発信させながら高速で回転させ, 作業区域の外部に設け た「コーナー・キューブ」からの反射光を読み取る. そ して，図7に示すよらに 3 点のコーナーキューブまでの 角度を知ることにより, ロボット本体の $\mathrm{X}, \mathrm{Y}$ 座標と向 きをリアルタイムで得ることができる，建筑現場では， 鉄骨柱などレーザー光の障害物が想定されるので, 3 点 を越える基準点を同時に設定しておき, 各位置から最低 3 点が見通せるものとしている.なお， 3 点からのデー

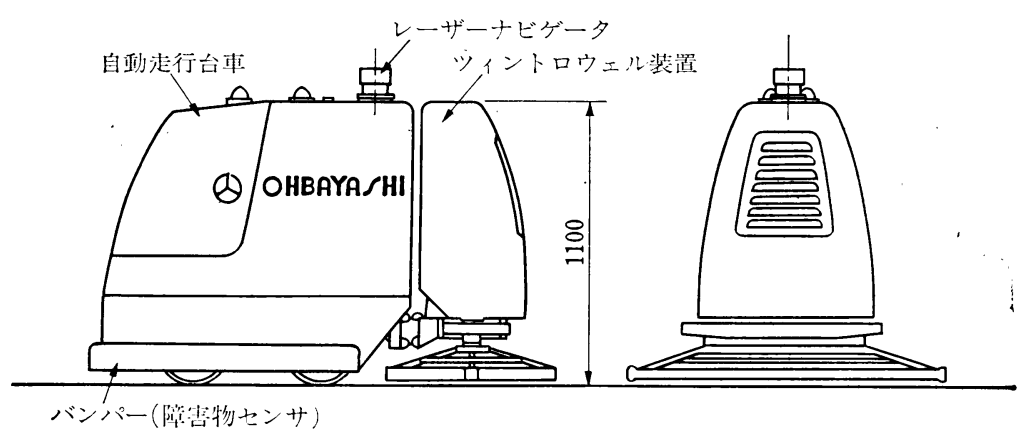

図 6 床作業ロボット外観図 


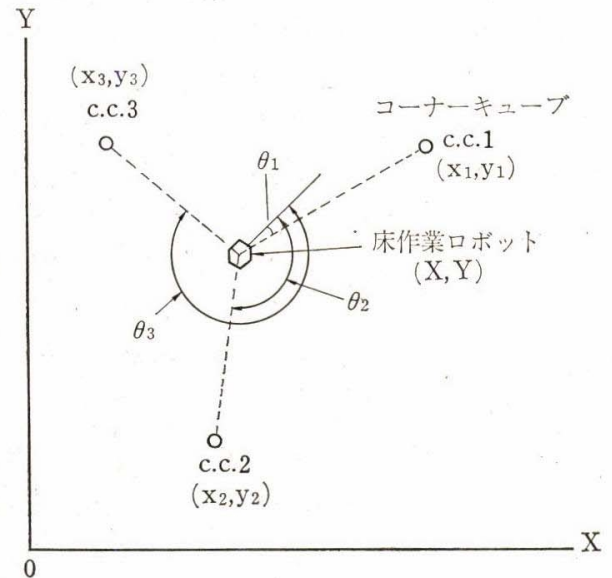

図 7 レーザー位置検出方法の原理

タが得られない場合には、ロボットの内界センサ（車輪 転回転量）により走行を続け、レーザー位置検出のでき る場所で再びレーザーによる走行誘導を行う．レーザー は, 人体への安全のため最小限の出力に抑えているが, 現状で約 $50 \mathrm{~m}$ まで検出能力があり, 一度に広範囲の作 業が可能である.

\subsection{4 測定精度及びその他}

予定軌道と実際の走行経路との誤差を $1 \mathrm{~m}$ 間隔で計 測した結果を図 8 と示す. 誤差平均 $3.4 \mathrm{~cm}$ と高い精度 の走行制御結果が得られている.

この方式では，(1)基準点の位置を变党ずに走行経路を 自由にデータで変更できる, (2)絶対座標系での走行誘導 のため誤差累積がない,などの利点がある.

\section{5. ま と め}

建築現場に和汀る作業の特殊性から求められる移動口 ボットの要件や現状について, 簡単に記述した. 建築現 場での作業は単純なものが多いが, その移動機能に求め られるものは, 走行経路の自由な設定や高い精度の位置 決め, 厳しい環境条件下での使用, 自律走行など, 製造 業のそれに比較して格段に高度な技術である.

開発事例として，3件の位置決めシステムについて紹 介した、いずれも二次元上の移動で，外部に基準点を設 け，自己位置をリアルタイムで計測するものである，そ して, その測定精度は，十分目的を満足するものである ことを確認した. 位置決め方式は, 対象作業条件に大き

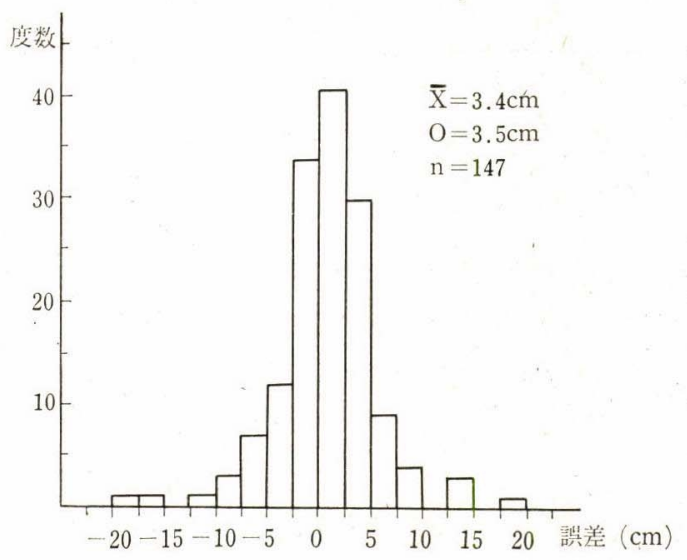

図 8 床作業ロボット走行位㯰誤差

く影響されるが,これらに影響を受けない, より自由度 の高いシステムとして，走行経路に依存しない位置基準 設定方法などの開発が望まれる.

\section{参考 文 献}

1) 汐川孝他：建設用ロボットの走行・位置決め制御につい て, 第 2 回建築施工ロボットシンポジウム予稿集, 1988. 2. 25, 26 (pp. 25-30)

2) T. Shiokawa et al. "NAVIGATION/POSITIONING CONTROL OF MOBILE ROBOTS FOR CONSTRUCTION" 5 th International Symposium on Robotics in Construction 1988.6 (pp. 589-589)

3) 竹本靖他 : 大林組の建設用ロボット, ロポット, No.58 (財)日本産業用ロボット工業会, 1987.6 (pp. 19-29)

4）汐川孝：自律走行式床作業ロボットの開発, 建設の機械 化, 日本建設機械化協会, 第457号, 1988.3 (pp. 48-52)

5）建設ロポット特集，建設の機械化，日本建設機械化協会， 第 460 号, 1988.6.

6) 特集, 建設ロボット全研究，施工，彰国社， 1988.5, No. 271 .

7）第 $1 \sim 3$ 回建築施工ロボットシンポジュウム予稿集, 日 本建築学会材料施工委員会, 1987.2 1989. 2

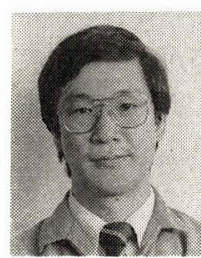

\section{汐川 孝}

(Takashi SHIOKAWA)

昭和 47 年北海道大学工学部建築工学科 卒業. 同年, (株) 大林組に入社し, 以来 技術研究所にて，建築施工にお沙る管理技 術および工事用ロボットの研究・開発に従 事. 現在, 同所建築第一研究室副主任研究

員, 建築学会会員, (財) 日本産業用ロボット工業会会員. 